\title{
KAJIAN PERSEPSI DAN POTENSI PENGEMBANGAN KAWASAN PARIWISATA PULAU KECIL Studi Kasus: Kawasan Pantai Padang Melang Kecamatan Jemaja Kabupaten Natuna
}

\author{
Indra Cahyadinata \\ Staf Pengajar Fakultas Pertanian Universitas Bengkulu
}

\begin{abstract}
Small Islands are potential area to be developed becoming tourism area. Jemaja Island as one of the small islands have potency to be able to be developed, which recognized with Padang Melang area. This research is aimed to know perception of society regarding to development of the area and compile tourism potencies that can be developed. Method the used is descriptive method with SWOT analysis. Result of this research indicates that society very support development of tourism (with good perception). Tourism potency is able to be developed including coastal tourism, maritime tourism, natural tourism and history tourism. Development strategy that recommended involve settlement and development of package of tourism, development of tourism facility, adding local transportation facility, opening flight and applying of base on community development in development of tourism.
\end{abstract}

Keyword : small island, coastal tourism, community development

\section{PENDAHULUAN}

Pulau Jemaja, yang sekaligus juga sebagai Kecamatan Jemaja, merupakan salah satu pulau yang terletak di gugusan Kepulauan Anambas. Kepulauan Anambas merupakan salah satu gugusan pulau di Kabupaten Natuna. Kecamatan Jemaja memiliki luas wilayah sekitar 14.924,6 $\mathrm{km}^{2}$, yang terdiri dari $266,6 \mathrm{~km}^{2}$ wilayah daratan (1,79\% dari total luas wilayah) dan wilayah lautan seluas $14.658 \mathrm{~km}^{2} \quad(98,21 \%$ dari total luas wilayah). Kondisi ini menggambarkan bahwa Kecamatan Jemaja memiliki sumberdaya perikanan dan kelautan yang jauh lebih besar dibandingkan sumberdaya yang ada di wilayah daratan.

Gugusan kepulauan Jemaja yang merupakan salah satu kepulauan kecil, merupakan aset yang mempunyai potensi besar untuk dimanfaatkan, selain karena lokasinya yang berdekatan dengan jalur lalu lintas internasional, berbatasan dengan Malaysia, juga dekat dengan Pulau Kalimantan (Khususnya Kalimantan Barat yang dapat diakses melalui jalan laut (4 jam), disamping 
didukung oleh pemandangan alam, kondisi alam dan pantai yang indah. Pada wilayah ini telah dibangunnya perumahan penduduk sebagai masyarakat nelayan.

Salah satu potensi yang dimiliki oleh kepulauan kecil adalah potensi pariwisata. Di Pulau Jemaja, terdapat banyak potensi pariwisata yang dapat dikembangkan. Potensi-potensi yang ada terpusat pada pulau jemaja bagian utara, yang lebih dikenal dengan nama kawasan pariwisata Pantai Padang Melang. Kawasan ini merupakan pantai yang indah dan landai dengan bentang cukup besar serta hamparan pasir putih, akan menjadi daya tarik tersendiri bila dikembangkan sebagai kawasan wisata. Namun, pemanfaatan Pulau Jemaja diharapkan dapat meliputi kawasan lahan daratan, pantai/pesisir dan perairannya sehingga semua kepentingan dapat terakomodasi dengan selaras baik dari aspek ekonomi/pemberdayaan masyarakat maupun aspek kelestarian lingkungan, agar dapat dikelola dengan baik untuk sebesar-besarnya kesejahteraan masyarakat setempat.

Untuk itu, perlu dilakukan kajian tentang persepsi masyarakat terhadap pengembangan pariwisata pantai Padang Melang, sekaligus menyusun potensi pariwisata yang dapat dikembangkan.

\section{METODOLOGI PENELITIAN}

Data yang digunakan dalam studi kelayakan ini terdiri dari 2 (dua) jenis, yaitu data primer dan data sekunder. Data sekunder diperoleh dari instansi pemerintah, terutama di Kecamatan Jemaja. Beberapa data sekunder yang dikumpulkan meliputi aspek pendidikan, kependudukan serta sarana dan prasarana. Data sekunder dalam penelitian ini disajikan dalam bentuk tabel dan diberikan penjelasan secara deskriptif. Penyajian data seperti ini dimaksudkan untuk memberikan informasi yang bersifat lebih informatif dan lebih mudah untuk dipahami.

Data primer utama dalam kajian ini diperoleh dengan menggunakan instrumen kuesioner, yaitu daftar yang berisi pertanyaan-pertanyaan yang dijadikan sebagai panduan dalam menggali 
data dan informasi dari masyarakat tentang karakteristik responden dan persepsi terhadap pengembangan pariwisata Padang Melang. Data primer juga dikumpulkan dengan metode FGD (fucus group discussion), dengan mengumpulkan beberapa orang tokoh dan pemuka masyarakat untuk dilakukan diskusi terarah tentang pengembangan pariwisata Pantai Padang Melang.

Responden dalam kajian studi kelayakan ini dipilih secara acak (simple random sampling) terhadap masyarakat yang ada di Kecamatan Jemaja. Pada design awal, jumlah responden tidak ditentukan. Tetapi pemilihan responden akan berhenti jika telah ditemukan kecenderungan jawaban yang sama terhadap pertanyaan yang diajukan. Dengan menggunakan metode ini, maka wawancara dengan menggunakan kuesioner berhenti pada responden ke-12 (dua belas). Dengan demikian, jumlah responden dalam wawancara sebanyak 12 orang.

Data primer yang diperoleh dari wawancara dengan menggunakan kuesioner terhadap 12 orang responden terdiri dari dua bentuk data, yaitu data karakteristik responden dan data persepsi responden terhadap pengembangan pariwisata Pantai Padang Melang. Pengolahan data karakteristik responden dilakukan dengan membuat tabulasi dan disajikan secara deskriptif. Sedangkan data persepsi diolah dengan memberikan skor 3 untuk jawaban setuju, skor 2 untuk jawaban kurang setuju dan skor 1 untuk jawaban tidak setuju dari setiap pertanyaan atau pernyataan persepsi yang diajukan. Pemberian skor ini hampir sama dengan skala Likert, yang umumnya menggunakan angka 1, 3, dan 5. Pemberian skor yang lebih tinggi dimaksudkan untuk memberikan pengertian yang lebih baik dibandingkan dengan skor yang rendah. Hasil skoring terhadap setiap pertanyaan/pernyataan tersebut dihitung frekuensinya berdasarkan jumlah responden dan disajikan dalam bentuk tabel dengan diberikan penjelasan secara deskriptif.

Untuk menentukan persepsi secara keseluruhan per individu tentang pengembangan pariwisata pantai Padang Melang, maka dilakukan dengan menjumlahkan seluruh skor dari semua 
pertanyaan/pernyataan yang diajukan. Persepsi tersebut dibedakan menjadi 3 kelas (kategori) dengan penentuan interval kelas adalah :

$$
\text { Interval = (nilai tertinggi }- \text { nilai terendah }) / \text { jumlah kelas }
$$

Data primer yang diperoleh dari FGD dianalisis dengan menggunakan analisis SWOT. Menurut Rangkuti (2002), analisis SWOT adalah identifikasi berbagai faktor secara sistematis untuk merumuskan strategi perusahaan yang didasarkan pada logika yang dapat memaksimalkan kekuatan (strengths) dan peluang (opportunities), namun secara bersamaan dapat meminimalkan kelemahan (weaknesses) dan ancaman (threats). Analisis SWOT dilakukan berdasarkan asumsi bahwa suatu strategi yang efektif akan memaksimalkan kekuatan dan peluang serta meminimalkan kelemahan dan ancaman perusahaan. Apabila diterapkan secara tepat, asumsi sederhana ini mempunyai implikasi yang berpengaruh untuk merancang suatu strategi yang berhasil (Tunggal diacu dalam Hidayat 2003). Jika kita telah mengenal kekuatan dan kelemahan diri sendiri dan mengetahui kekuatan dan kelemahan lawan atau orang lain, sudah dapat dipastikan kita akan memenangkan pertempuran (Sun Tzu diacu dalam Taufik 2002).

Dengan demikian, analisis SWOT merupakan analisis yang digunakan untuk merumuskan suatu alternatif strategi pengembangan perusahaan dengan mengetahui dan menginventarisasi faktor-faktor sebagai berikut (Yoeti diacu dalam Hidayat 2003) :

1. Kekuatan atau faktor-faktor yang menguntungkan, yaitu adalah unsur yang dimiliki oleh perusahaan yang bisa membantu mencapai prestasi atau keberhasilan.

2. Kelemahan atau faktor-faktor yang tidak menguntungkan, yaitu unsur yang dimiliki oleh perusahaan yang bisa menyebabkan kinerja perusahaan menjadi buruk atau menghambat untuk mencapai keberhasilan.

3. Peluang atau kesempatan yang dapat menjadi faktor-faktor yang menguntungkan, yaitu unsur lingkungan yang berada di luar kendali perusahaan yang dapat menguntungkan perusahaan. 
4. Ancaman atau faktor-faktor yang dapat mendatangkan kerugian, yaitu unsur lingkungan yang berada di luar kendali perusahaan yang tidak menguntungkan perusahaan dan dapat mengganggu /menghalangi suatu kegiatan/usaha.

Penelitian menunjukkan bahwa kinerja perusahaan dapat ditentukan oleh kombinasi faktor-faktor internal dan eksternal. Kedua faktor tersebut harus dipertimbangkan dalam analisis SWOT. Analisis SWOT membandingkan antara faktor eksternal peluang dan ancaman dengan faktor internal kekuatan dan kelemahan (Rangkuti 2002).

Model matriks analisis SWOT dapat dilihat pada tabel berikut :

Tabel 1. Model Matriks Analisis SWOT

\begin{tabular}{lll}
\hline EFAS & Kekuatan (S) & Kelemahan (W) \\
\hline Peluang ( O ) & Strategi SO & Strategi WO \\
Ancaman ( T $)$ & Strategi ST & Strategi WT \\
\hline
\end{tabular}

Sumber: Rangkuti (2002).

\section{HASIL DAN PEMBAHASAN}

Padang Melang memiliki legenda tersendiri. Beberapa arti nama tersebut adalah:

- Padang Melang terdiri dari dua suku kata, yaitu Padang yang berarti padang/lapangan dan Melang yang berarti Lapangan Luas. Meskipun terjadi pengulangan kata lapangan, Padang Melang dapat dianggap memiliki arti Padang atau Lapangan yang luas. Hal ini juga dibuktikan bahwa kawasan Padang Melang merupakan kawasan pantai yang sangat luas sehingga menyerupai sebuah lapangan.

- Padang Melang sering juga disebutkan oleh masyarakat setempat dengan nama Melang Sinambun. Kata-kata ini terdiri dari beberapa pecahan suku kata yang bunyinya jika diucapkan hampir sama dalam bahasa cina yang memiliki makna tensendiri. Pecahan suku kata tersebut adalah : 
1. Me : orang

2. Lang : ramai

3. Sina : mati

4. Mbun : arah timur

Gabungan pecahan suku kata Melang Sinambun memiliki arti ramai orang mati di arah timur. Arah timur yang dimaksud adalah arah timur-nya Padang Melang, yang saat ini sangat banyak terdapat kuburan. Namun tidak ada ada informasi yang jelas dan tidak ada satu pun juga yang mengetahui kuburan-kuburan tersebut merupakan kuburnya siapa dan kapan mereka dikuburkan.

Persepsi merupakan pandangan atau pendapat umum individu terhadap sesuatu objek yang menjadi sasaran. Persepsi masyarakat terhadap pengembangan pariwisata Pantai Padang Melang Kecamatan Jemaja Kabupaten Natuna adalah pandangan masyarakat terhadap pembangunan pengembangan pariwisata Pantai Padang Melang.

Pembangunan suatu proyek seringkali menimbulkan permasalahan bagi lingkungan dan masyarakat sekitar proyek. Telah banyak pengalaman di beberapa tempat di Indonesia akibat pembangunan suatu proyek menimbulkan permasalahan kehidupan ekonomi, sosial budaya dan lainnya. Oleh karena itu pengkajian terhadap persepsi masyarakat sekitar pembangunan proyek sangat perlu untuk dilakukan guna mengetahui sejauh mana anggapan dukungan yang diberikan oleh masyarakat sekitar terhadap proyek yang dilakukan. Penilaian persepsi terhadap pengembangan pariwisata Pantai Padang Melang Kecamatan Jemaja Kabupaten Natuna menggunakan indikator berupa pernyataan-pernyataan yang jawabannya merupakan penilaian dari masyarakat sekitar proyek itu sendiri. Pembahasan masing-masing bentuk pernyataanpernyataan tersebut disajikan di bawah ini. 
Tabel 2. Pertanyaan / Pernyataan Responden tentang Pengembangan Pariwisata

\begin{tabular}{|c|c|c|c|}
\hline \multirow{2}{*}{ Pernyataan / Pertanyaan } & \multicolumn{3}{|c|}{ Frekuensi } \\
\hline & $a$ & b & C \\
\hline $\begin{array}{l}\text { Pariwisata pantai Padang melang sangat potensial sangat untuk } \\
\text { dikembangkan }\end{array}$ & 12 & 0 & 0 \\
\hline Pantai Padang Melang dapat dikembangkan untuk pariwisata pantai & 12 & 0 & 0 \\
\hline Pantai Padang Melang dapat dikembangkan untuk pariwisata bahari & 12 & 0 & 0 \\
\hline $\begin{array}{l}\text { Kawasan Pantai Padang Melang juga dapat dikembangkan sebagai } \\
\text { agrowisata }\end{array}$ & 12 & 0 & 0 \\
\hline $\begin{array}{l}\text { Saat ini, sudah banyak wisatawan baik dalam negeri maupun luar negeri } \\
\text { yang datang ke Padang Melang }\end{array}$ & 2 & 8 & 2 \\
\hline Transportasi menuju Padang Melang sudah cukup dan memuaskan & 0 & 3 & 9 \\
\hline $\begin{array}{l}\text { Fasilitas penginapan (baik rumah penduduk maupun penginapan } \\
\text { komersial) sudah cukup untuk menampung wisatawan }\end{array}$ & 0 & 0 & 12 \\
\hline $\begin{array}{l}\text { Pengembangan Pantai Padang Melang harus dilakukan oleh pemerintah } \\
\text { dan investor }\end{array}$ & 11 & 0 & 1 \\
\hline $\begin{array}{l}\text { Pengembangan Pantai Padang Melang juga harus melibatkan } \\
\text { masyarakat }\end{array}$ & 12 & 0 & 0 \\
\hline $\begin{array}{l}\text { Secara pribadi sebagai anggota masyarakat, saya sangat mendukung } \\
\text { pengembangan wisata Pantai Padang Melang }\end{array}$ & 12 & 0 & 0 \\
\hline
\end{tabular}

Keterangan : a (setuju), b (kurang setuju), c (tidak setuju).

Jika memperhatikan indikator pertama dalam menilai persepsi masyarakat terhadap pengembangan pariwisata Pantai Padang Melang, maka pariwisata pantai Padang melang sangat mempunyai potensi untuk dikembangkan menjadi pariwisata yang lebih baik dan besar. Indikator pertanyaan kedua dalam menilai persepsi masyarakat terhadap pengembangan pariwisata Pantai Padang Melang, yakni dengan pernyataan "Pantai Padang Melang dapat dikembangkan untuk pariwisata pantai" jawaban masyarakat yang menjadi responden penelitian ini, ia menyatakan setuju dengan frekuensi sebesar 12. ini berarti bahwa seluruh responden menyatakan setuju terhadap pernyataan tersebut. Dengan demikian pantai Padang Melang sangat mempunyai potensi untuk dikembangkan menjadi pariwisata pantai.

Indikator pertanyaan ketiga dalam menilai persepsi masyarakat terhadap pengembangan pariwisata Pantai Padang Melang, yakni dengan pernyataan "Pantai Padang Melang dapat 
dikembangkan untuk pariwisata bahari" jawaban masyarakat yang menjadi responden penelitian ini, ia menyatakan setuju dengan frekuensi sebesar 12. Hal ini berarti bahwa seluruh responden menyatakan setuju terhadap pernyataan tersebut. Dengan demikian pantai Padang Melang sangat mempunyai potensi untuk dikembangkan menjadi pariwisata bahari.

Indikator pertanyaan ke empat dalam menilai persepsi masyarakat terhadap pengembangan pariwisata Pantai Padang Melang, yakni dengan pernyataan "Kawasan Pantai Padang Melang juga dapat dikembangkan sebagai agrowisata "jawaban masyarakat yang menjadi responden penelitian ini, ia menyatakan setuju dengan frekuensi sebesar 12. Ini berarti bahwa seluruh responden menyatakan setuju terhadap pernyataan tersebut. Dengan demikian pantai Padang melang sangat mempunyai potensi untuk dikembangkan menjadi kawasan agrowisata. Penjelasan yang sama seperti penjelasan tentang indikator di atas juga sama dengan penjelasan pernyataan atau pertanyaan yang belum dijelaskan.

Dari indikator-indikator pertanyaan atau pernyataan yang diajukan kepada responden tentang persepsi masyarakat terhadap pengembangan pariwisata pantai Padang Melang, maka persepsi masyarakat tersebut dapat diklasifikasikan menjadi 3 (tiga) kategori. Secara rinci, kategori dan persepsi masyarakat tersebut adalah :

Tabel 3. Persepsi Masyarakat terhadap Pengembangan Pariwisata Pantai Padang Melang

\begin{tabular}{clccc}
\hline No & Kategori Persepsi & Skor & Frekuensi (orang) & Persentase (\%) \\
\hline 1 & Baik & $18-30$ & 12 & 100 \\
2 & Sedang & $30-48$ & 0 & 0 \\
3 & Tidak Baik & $48-60$ & 0 & 0 \\
\hline
\end{tabular}

Tabel di atas memperlihatkan bahwa persepsi masyarakat Kecamatan Jemaja terhadap pengembangan pariwisata pantai Padang Melang berada dalam kategori baik. Kategori baik ini juga mengandung pengertian bahwa masyarakat setuju Pantai Padang Melang dikembangkan dan masyarakat siap mendukung program tersebut. Ini juga mengandung pengertian bahwa 
masyarakat siap menerima kehadiran orang luar sebagai wisatawan baik dalam negeri maupun mancanegara.

Secara umum analisis SWOT lebih diarahkan pada pengidentifikasian kekuatan, kelemahan, peluang, ancaman dan pendekatan pengembangan ke depan. Strategi yang dihasilkan merupakan upaya untuk mengembangkan pariwisata Pantai Padang Melang secara terpadu.

Tabel 4. Hasil Analisis SWOT

\begin{tabular}{|c|c|c|}
\hline EKSTERNAL & $\begin{array}{l}\text { KEKUATAN (S) : } \\
\text { S1. Panjang garis pantai } \pm 8 \\
\text { km dengan pantai yang } \\
\text { landai } \\
\text { S2. Terdapat potensi Wisata } \\
\text { yang dapat dikembangkan } \\
\text { yang didukung oleh } \\
\text { masyarakat }\end{array}$ & $\begin{array}{l}\text { KELEMAHAN }(\mathrm{W}) \text { : } \\
\text { W1. Potensi Wisata belum } \\
\text { dikelola dengan baik } \\
\text { W2. Sarana transportasi } \\
\text { menuju dan lokal Jemaja } \\
\text { masih sangat minim }\end{array}$ \\
\hline $\begin{array}{l}\text { PELUANG }(0) \text { : } \\
\text { O1. Kebijakan } \\
\text { pembangunan } \\
\text { pariwisata dari BPID } \\
\text { O2. Sarana transportasi } \\
\text { pesawat Tanjung } \\
\text { Pinang - Palmatak }\end{array}$ & $\begin{array}{l}\text { Strategi SO : } \\
\text { - Penataan dan } \\
\text { Pengembangan Paket } \\
\text { Wisata } \\
\text { - Pembangunan Fasilitas } \\
\quad \text { pariwisata }\end{array}$ & $\begin{array}{l}\text { Strategi WO: } \\
\text { - } \quad \text { Menambah fasilitas } \\
\text { transportasi lokal dan } \\
\text { Membuka jalur penerbangan } \\
\text { - Pelibatan pengusaha / calon } \\
\text { investor }\end{array}$ \\
\hline $\begin{array}{l}\text { ANCAMAN }(\mathrm{T}) \text { : } \\
\text { T1.Kehadiran orang luar } \\
\text { memarginalkan } \\
\text { masyarakat setempat }\end{array}$ & $\begin{array}{l}\text { Strategi ST: } \\
\text { Penerapan community base } \\
\text { development dalam } \\
\text { pengembangan pariwisata }\end{array}$ & $\begin{array}{l}\text { Strategi WT : } \\
\text { Penerapan community base } \\
\text { development dalam } \\
\text { pengembangan pariwisata }\end{array}$ \\
\hline
\end{tabular}

Kekuatan utama dalam pengembangan pariwisata pantai Padang Melang adalah:

- Pantai Padang Melang, sesuai dengan namanya, merupakan padang atau lapangan yang luas dengan bentuk pantai yang sangat landai. Panjang total pantai sekitar $8 \mathrm{~km}$, menjadi lokasi yang sangat layak untuk dikembangkan sebagai pariwisata.

- Sebagai pantai yang panjang dan landai, Padang Melang sangat cocok dimanfaatkan untuk pengembangan pariwisata pantai, dimana tersedia ruang yang banyak bagi wisatawan untuk 
berjemur. Selain pariwisata pantai, dapat pula dikembangkan pariwisata bahari yang berbasiskan keindahan di bawah laut seperti terumbu karang. Potensi wisata lain yang dapat dikembangkan di wilayah Kecamatan Jemaja dan Jemaja Timur adalah wisata alam (air terjun) dan wisata sejarah. Wisata sejarah berupa meriam dan barang pecah belah (seperti guci, piring dan lain-lain) yang ditemukan oleh masyarakat ketika menggali tanah untuk membuat sumur atau rumah.

Meskipun terdapat kekuatan yang luar biasa, pengembangan wisata Padang Melang memiliki kelemahan, antara lain:

- Potensi wisata yang ada belum dikelola dengan baik seperti pantai, terumbu karang dan air terjun yang tidak terkelola dengan baik. Disamping itu, potensi sejarah yang ada seperti meriam dan barang pecah belah yang merupakan peninggalan zaman tempo dulu masih tersebar pada rumah-rumah penduduk.

- Sarana transportasi baik dari luar Jemaja menuju Jemaja dan transportasi lokal Jemaja masih dirasakan sangat kurang. Saat ini, transportasi menuju Jemaja hanya menggunakan transportasi laut dari Tanjung Pinang dan Ranai dengan frekuensi pelayaran sekitar satu kali setiap minggu-nya. Jika cuaca buruk, maka tidak ada kapal yang berlayar menuju dan keluar dari Jemaja.

Yang menjadi peluang dalam pengembangan wisata Padang Melang adalah:

- Kebijakan Badan Promosi dan Investasi Daerah (BPID) Kabupaten Natuna untuk membuat kajian kelayakan pengembangan pariwisata pantai Padang Melang dapat dijadikan sebagai titik awal untuk pengembangan pariwisata di Kecamatan Jemaja dan Kecamatan Jemaja Timur. Kebijakan ini juga diharapkan sebagai titik awal perhatian pemerintah kabupaten dan diharapkan pula dapat direspon oleh dinas/instansi dan pihak-pihak yang terkait dengan pengembangan pariwisata di Kabupaten Natuna. 
- Khusus untuk transportasi udara, saat ini sudah ada jalur penerbangan dari Tanjung Pinang Palmatak - Ranai (PP) yang dilayani oleh PT Riau Airlines dengan frekuensi penerbangan sekitar 2 kali seminggu. Disamping itu, juga terdapat penerbangan dari Palmatak - Halim Perdana Kusuma (Jakarta) yang dilayani oleh PT Conoco Philips. Namun hingga saat ini, penerbangan PT Conoco Philips hanya untuk lingkungan yang sangat terbatas.

Ancaman utama dalam pengembangan pariwisata Padang Melang adalah marginalisasi masyarakat setempat. Pengambangan pariwisata menjadi faktor penarik sekaligus faktor pendorong bagi masyarakat luar Jemaja dan Jemaja Timur untuk membuka usaha baru. Dengan kondisi ini, dikhawatirkan masyarakat setempat akan menjadi penonton kemajuan daerahnya sendiri. Pada FGD berkembang harapan bahwa dengan adanya pembangunan pariwisata memberikan trickle down effect efek rembesan), bukannya back wash (pencucian) bagi masyarakat setempat.

Rumusan strategi yang diperoleh dari analisis SWOT diatas merupakan rumusan strategi yang bertujuan untuk memanfaatkan kekuatan dan peluang serta meminimalkan kelemahan dan ancaman, dimana dalam implementasinya harus melibatkan masyarakat, pemerintah dan pihakpihak terkait lainnya. Dengan strategi tersebut, diharapkan pemerintah dan masyarakat memiliki kewenangan masing-masing dalam pemanfaatan sumberdaya, yang dikenal dengan istilah komanajemen. Penyusunan tabel SWOT di atas pun telah melibatkan masyarakat pesisir Kecamatan Jemaja.

Strategi SO dirumuskan dengan memanfaatkan kekuatan dan peluang seperti yang telah dijelaskan di atas. Stategi SO tersebut adalah:

- Penataan dan pengembangan Paket Wisata di Kecamatan Jemaja dan Kecamatan Jemaja Timur

Paket wisata yang dapat dikembangkan adalah: 
1. Pariwisata Pantai. Pariwisata Pantai Padang Melang dapat dijadikan sebagai tujuan pariwisata pantai utama ketika wisatawan melakukan aktivitas wisata. Kondisi arus dan gelombang yang relatif tenang dapat dimanfaatkan untuk mandi/berenang dan pantai yang panjang dengan topografi yang landai dapat dijadikan ruang untuk berjemur. Di antara pantai yang panjang tersebut, juga terdapat pantai pasir putih yang indah dan terdapat pula pasir lakang dimana tekstur pasir tersebut menyerupai bentangan rambut yang panjang. Legendanya, pada zaman dahulu ada seorang putri yang memiliki rambut yang sangat panjang dan tatkala selesai mandi, rambut sang putri dikeringkan dengan cara dijemur menggunakan jemuran seperti jemuran pakaian. Sang putri dibunuh dan rambutnya membentang membentuk tekstur pasir pantai. Di Pantai Padang Melang juga terdapat pasir yang ketika diinjak atau dipukul berbunyi seperti bunyi gong. Konon, pada wilayah itu dulunya tertimbun batu gong yang digunakan oleh nakhoda kapal untuk memberikan aba-aba kepada ABK. Selain Pantai Padang Melang, pariwisata pantai yang dapat disuguhkan pada wisatawan adalah Pantai Kusik dan Pantai Nguan di Desa Rewak, Pantai Pulau Ayam, Pantai Pulau Dewata (Dara), Pantai Stika, Teluk Tampuk dan Pantai Belusan.

2. Pariwisata Bahari. Pengembangan pariwisata bahari dalam bentuk diving bertujuan menjual keindahan bawah laut berupa terumbu karang, yang banyak terdapat di sekitar pantai Padang Melang. Berdasarkan survey, disekitar perairan laut dekat pantai Padang Melang juga ditemukan bekas tali jangkar kapal yang diduga tenggelam beberapa puluh tahun yang lalu, yang saat ini sudah mulai hidup terumbu karang dengan bentuk yang memanjang sepanjang bentangan tali pada dasar lautan.

3. Pariwisata Alam. Wisata alam lebih berfokus pada wilayah daratan, dimana wisata alam yang dapat dikembangkan antara lain air terjun Neraja di Desa Ulu Maras kecamatan Jemaja Timur. Saat survey, kondisi air terjun masih dengan lingkungan yang alami dan sudah terdapat 
beberapa pondokan untuk istirahat di sekitar air terjun (termasuk tempat untuk mandi). Namun jelas terlihat bahwa fasilitas yang ada kurang terawat yang kemungkinan salah satu penyebabnya adalah minimnya kunjungan wisatawan ke sana. Disamping itu, juga bisa dikembangkan wisata alam gunung yang terdapat pada dua gunung, yaitu Gunung Datuk (yang secara administratif terdapat di Kelurahan Letung dan Desa Rewak) dan Gunung Puding (yang secara administratif terdapat di Kelurahan Letung). Wisata alam lain yang dapat dikembangkan adalah wisata di Pulau Penanam, yang merupakan habitat penyu.

4. Pariwisata Sejarah. Dalam sejarah, Kecamatan Jemaja dan Kecamatan Jemaja Timur pernah diduduki oleh Belanda dan sering didatangi oleh perompak. Ketika perompak datang, masyarakat umumnya menyembunyikan harta-benda yang dimiliki dengan cara menguburkannya dalam tanah. Banyak pula penduduk yang mati di bunuh oleh perompak ketika tidak menemukan harta benda dan tidak ada anggota keluarga yang tahu dimana hartabenda disembunyikan oleh anggota keluarga yang mati terbunuh. Disamping itu, daerah ini juga sempat dijadikan sebagai tempat pelarian bagi orang Vietnam ketika terjadi perang saudara di Vietnam. Kejadian-kejadian tersebut menjadikan Kecamatan Jemaja dan jemaja Timur menjadi lokasi sejarah yang menarik. Salah satunya, di salah satu masjid di Desa Ulu Maras, terdapat sekitar 3 meriam yang terdiri dari 2 meriam besar dan 1 meriam kecil. Di Ulu Maras juga banyak ditemukan barang-barang antik, yang saat ini keberdaannya tersebar pada rumah-rumah penduduk. Di Pulau Bangkai, terdapat Mercusuar dengan bangunan lama yang menggunakan batu bata merah berstempel Batavia dan mercusuar ini dibangun oleh Belanda pada Tahun 1817. Di Pulau Kuku banyak terdapat kuburan orang Vietnam, dimana kuburan tersebut hingga saat ini banyak dikunjungi oleh orang Vietnam, bahkan pernah ada seorang anak yang memindahkan kuburan orang tuanya dari Pulau Kuku ke Vietnam. Di Pulau Kuku ini juga diyakini oleh masyarakat bahwa terdapat sangat banyak harta benda dan barang antik 
peninggalan orang-orang Vietnam. Di sekitar perairan laut dangkal wilayah Jemaja Timur, juga terdapat adanya karang yang menyerupai kuburan dan dalam kuburan karang tersebut diduga terdapat barang-barang antik yang tinggi akan nilai sejarahnya.

- Pembangunan Fasilitas Pariwisata. Fasilitas pertama yang paling dibutuhkan ketika pariwisata Padang Melang dikembangkan adalah pembangunan fasilitas penginapan, yang dalam istilah pariwisata dikenal dengan Resort. Resort yang baik adalah resort yang memiliki lokasi yang juga menjual view keindahan alam dengan lokasi disekitar Pantai Padang Melang. Pada lokasi-lokasi wisata, perlu dibangun pondok-pondok kecil yang terbuka dan dapat dimanfaatkan untuk wisatawan beristirahat. Di kawasan pariwisata pantai dan pariwisata bahari, perlu juga dibangun fasilitas pemandian air tawar, yang umumnya dilakukan wisatawan setelah menyelam dan berenang. Untuk menunjang aktivitas diving yang dilakukan wisatawan, perlu juga adanya jasa penyewaan peralatan-peralatan yang dibutuhkan. Khusus untuk barang-barang antik yang keberadaannya masih tersebar, perlu pula di bangun suatu gedung seperti musem agar benda-benda bersearah tersebut lebih tertata dengan rapi dan lebih menarik

Strategi WO adalah:

a. Menambah fasilitas transportasi lokal dan Membuka jalur penerbangan

Salah satu peluang transportasi menuju ke arah Jemaja saat ini adalah adanya penerbangan dari Tanjung Pinang - Palmatak - Ranai (PP). Pengembangan pariwisata Padang Melang diharapkan pula diikuti dengan penambahan rute penerbangan Tanjung Pinang - Jemaja Palmatak - Ranai (PP). Dengan demikian, Jemaja semakin mudah dijangkau oleh wisatawan. Untuk itu, pemerintah perlu membangun bandar udara di Kecamatan Jemaja atau Jemaja Timur. Untuk transportasi laut, keberadaan pelabuhan yang bisa digunakan untuk bersandarnya kapal-kapal besar mutlak diperlukan. Saat ini, di Jemaja hanya ada pelabuhan 
perintis, dan bagi penumpang kapal non-perintis turun di tengah laut dengan resiko keselamatan yang mengkhawatirkan. Untuk menambah transportasi keluar dari Jemaja, perlu juga bekerja sama dengan PT Conoco Philips agar penerbangan perusahaan dari Palmatak ke Jakarta bisa dikomersialkan untuk masyarakat umum pada hari-hari tertentu, mengingat Palmatak bisa dijangkau dari Jemaja dengan speed \pm 1 jam. Disamping transportasi menuju dan keluar dari Jemaja, maka transportasi lokal seperti angkutan umum juga diperlukan untuk mempercepat mobilitas wisatawan dari suatu lokasi wisata ke lokasi wisata lain.

- Pelibatan pengusaha/calon investor. Pembangunan fasilitas dan sarana transportasi untuk menunjang pariwisata Padang Melang tidak bisa hanya dilakukan oleh pemerintah seluruhya. Harus ada pelibatan pihak ketiga untuk mengkaji lebih detail potensi investasi di Jemaja. Jika potensial, maka segenap stakeholder diharapkan dapat melakukan pembangunan dan promosi sesuai dengan kompetensi masing-masing, dimana promosi merupakan bagian penting dalam bauran pemasaran pariwisata.

Strategi ST yang meminimalkan ancaman dengan memanfaatkan kelemahan dan strategi WT yang meminimalkan ancaman dan meminimalkan kelemahan adalah penerapan community base development dalam pengembangan pariwisata. Pembangunan dan pengembangan pariwisata Pantai Padang Melang diharapkan dapat meningkatkan taraf hidup (kesejahteraan) masyarakat Kecamatan Jemaja dan Kecamatan Jemaja Timur. Oleh karena itu, pembangunan dan pengembangan pariwisata harus melibatkan partisipasi aktif masyarakat mulai dari perencanaan, implementasi dan pengawasan. Sumberdaya manusia yang bekerja pada supporting system harus memprioritaskan sumberdaya lokal dan beberapa fasilitas perlu juga diberikan kesempatan bagi masyarakat setempat untuk membangunnya, seperti transportasi lokal, jasa penyewaan peralatan selam, transportasi Jemaja - Palmatak. Dengan demikian, pembangunan pariwisata tidak menjadikan penduduk pribumi marginal dan terpinggirkan. 


\section{KESIMPULAN}

Berdasarkan kajian yang telah dilakukan, maka dapat diketahui bahwa masyarakat sangat mendukung pengembangan pariwisata di Kecamatan Jemaja, dengan persepsi yang baik. Potensi pariwisata yang dapat dikembangkan terdiri dari wisata pantai, wisata bahari, wisata alam dan wisata sejarah. Untuk mengembangkan potensi-potensi wisata yang ada, maka diperlukan strategi-strategi pengembangan, antara lain :

a. penataan dan pengembangan paket wisata,

b. pembangunan fasilitas pariwisata,

c. menambah fasilitas transportasi lokal,

d. membuka jalur penerbangan dan

e. penerapan community base development dalam pengembangan pariwisata.

\section{DAFTAR PUSTAKA}

[BPS]. 2005. Natuna dalam Angka. Kerjasama BPS dan Bappeda Kabupaten Natuna. Ranai.

Hidayat R. 2003. Inventarisasi Potensi Sumberdaya Wisata Alam di Wana Wisata Bunder dan Pengembangannya dengan Pendekatan Analisis SWOT. Tesis Program Pasca Sarjana IPB. Bogor.

Rangkuti F. 2002. Analisis SWOT Teknik Membedah Kasus Bisnis. Penerbit RT Gramedia Pustaka Utama. Jakarta.

Taufik. 2002. Analisis SWOT Pengembangan Usaha Kebun Campuran. Tesis Program Pasca Sarjana IPB. Bogor. 